\title{
Continuity of care in the Health Care Network: negotiation between users and professionals
}

\author{
Continuidade do cuidado na Rede de Atenção à Saúde: negociação entre usuários e \\ profissionais
}

\section{Continuidad del cuidado en la Red de Atención a la Salud: negociación entre usuarios y profesionales}

Maria Denise Schimith ${ }^{1}$, Ana Cristina Passarella Brêtas ${ }^{2}$, Maria de Lourdes Denardin Budó ${ }^{1}$, Bruna Sodré Simon ${ }^{3}$, Tifany Colomé Leal ${ }^{1}$, Dirce Maria Backes ${ }^{4}$

This study aimed to identify the negotiation and shared decision-making between professionals and users in a Family Health Unit and its influence on the continuity of care in the Health Care Network. Qualitative research created from a case study. One conducted 19 interviews, observation and document research. It was developed in a city in the countryside of Rio Grande do Sul, Brazil, in 2012. The results show that decisions used to happen unilaterally and that users and professionals looked for alternative ways to the continuity of care. It was not possible to identify the negotiation between professional and users and it was noticed that the user was alone looking for access. It is understood that primary care in the city researched needs to take responsibility for users and their access.

Descriptors: Patient Participation; Continuity of Patient Care; Unified Health System; Delivery of Health Care.

Objetivou-se identificar a negociação e tomada de decisão compartilhada entre profissionais e usuários em Unidade de Saúde da Família e sua influência na continuidade do cuidado na Rede de Atenção à Saúde. Pesquisa qualitativa, a partir de um estudo de caso. Foram realizadas 19 entrevistas, observação e busca em documentos. Desenvolveu-se em município do interior do Rio Grande do Sul, Brasil, em 2012. Os resultados apresentam que as decisões aconteciam unilateralmente e que usuários e profissionais buscavam caminhos alternativos para continuidade do cuidado. Não foi possível identificar a negociação entre trabalhadores e usuários e percebeu-se que o usuário se encontrava solitário na busca pelo acesso. Entende-se que a Atenção Básica no município pesquisado necessita assumir a responsabilidade pelo usuário e acesso deste. Descritores: Participação do Paciente; Continuidade da Assistência ao Paciente; Sistema Único de Saúde; Assistência à Saúde.

El objetivo fue identificar la negociación y la toma de decisiones compartidas entre profesionales y usuarios en Unidad de Salud de la Familia y su influencia en la continuidad del cuidado en la Red de Atención a la Salud. Investigación cualitativa, a partir de un estudio de caso. Fueron llevadas a cabo 19 entrevistas, observación y búsqueda de documentos. Se desarrolló en municipio del interior del Rio Grande do Sul, Brasil, en 2012. Los resultados muestran que las decisiones sucedían de manera unilateral y que usuarios y profesionales buscaban alternativas para continuidad de la atención. No se pudo identificar la negociación entre trabajadores y usuarios, y se observó que el usuario estaba solitario en la búsqueda de acceso. Se entiende que la Atención Primaria en la ciudad investigada necesita asumir la responsabilidad por el usuario y acceso de esto.

Descriptores: Participación del Paciente; Continuidad de la Atención al Paciente; Sistema Único de Salud; Prestación de Atención de Salud.

\footnotetext{
${ }^{1}$ Universidade Federal de Santa Maria, Santa Maria, RS, Brazil.

${ }^{2}$ Universidade Federal de São Paulo, São Paulo, SP, Brazil.

${ }^{3}$ Faculdade Integrada de Santa Maria, Santa Maria, RS, Brazil.

${ }^{4}$ Centro Universitário Franciscano, Santa Maria, RS, Brazil.
}

Corresponding author: Maria Denise Schimith

Rua João Goulart, 519, Camobi, CEP: 97105-220. Santa Maria, RS, Brazil. E-mail: ma.denise2011@gmail.com 


\section{Introduction}

Health users started to have a central role after the institutionalization of the Unified Health System, with community participation as a guiding principle. However, it is still necessary to build popular participation in everyday services. This theme takes a greater dimension when considering the processes of demographic, epidemiological and nutritional transition that have occurred in Brazil in recent years. With the increase of longevity and chronic conditions ${ }^{(1)}$, the longitudinality of care changes the way of conceiving and making health.

Given this scenario, care practices should aim at users' participation in decisions of treatment proposals. The emancipation of subjects must be constructed in order to overcome and control the determinants of their health, so that they can make their choices in a guided way(2).

User's participation can occur through a shared decision-making. This model depends on a few key elements that allow such participation, including the explicit encouragement from the professional to the user in order to participate and play an active role in the decision-making ${ }^{(3)}$. This practice can strengthen the autonomy and accountability of users for the therapeutic proposal chosen and for the path to be taken in the Health Care Network.

The Health Care Network is a proposal that is part of Integrated Health Systems worldwide ${ }^{(4)}$. The Pan American Health Organization advocates the need to strengthen health systems, in order to overcome fragmentation and move forward in providing more equitable and integral services ${ }^{(5)}$.

In Brazil, the Unified Health System, through the Law 8080/90, legitimizes that the actions are arranged in a regionalized and hierarchical way. It establishes as one of its objectives the assistance to people through the promotion and restoration of health, prevention of illnesses, assuming that it happens through the integration of prevention and care actions.
In 2010, the Ministry of Health published the Decree 4279/2010 conceptualizing the Health Care Network as the integrated organization of actions and health services of different technological densities, which seek to ensure comprehensive care. The Health Care Network aims to promote "systemic integration of health activities and services with provision of continuous, integral, quality, responsible and humane attention". It also aims to improve the performance of the Unified Health System, regarding access, equity and efficiency ${ }^{(6)}$, through a range of health services linked together by a single mission, by common and interdependent goals that allow integral attention to a given population ${ }^{(4)}$, being coordinated by the Primary Health Care.

However, there are big challenges for the Primary Health Care to assume the role of coordinator of a Health Care Network. Studies indicate obstacles for the consolidation of Primary Health Care, highlighting: the lack of an institutional policy directed towards its empowerment, the social representation of communities on this point of attention, the lack of social legitimacy, restricted managers' view, besides insufficient skilled resources, which results in a noticeable lack of support and logistics to support innovation of practices, welcoming of users and their connection to the Primary Health Care ${ }^{(4,7)}$.

In the Brazilian context, the commitment to change the model of Primary Health Care is the Family Health Strategy. The National Primary Care Policy, Ordinance 2488/2011, considers Family Health its strategic priority for expansion and consolidation of Primary Care. The Family Health Strategy should be the users' preferential contact, the main entrance door and the center of communication of the Health Care Network. The universality, accessibility, relationship, continuity of care, comprehensiveness of attention, accountability, humanization, equity and social participation are its guiding principles. The primary care should consider the subject in its uniqueness and sociocultural integration ${ }^{(8)}$.

Among the functions of the Primary Care in the 
Health Care Network, one highlights the coordination of care. The aforementioned ordinance says that the elaboration, monitoring and management of Unique Therapeutic Projects, as well as the organization of the users' flow between the points of attention of the Health Care Network should be functions of Primary Care. Being responsible for the users' care at any of these points through a horizontally, continuous and integrated relationship with the goal of producing a comprehensive and shared care management is also its function. For that, it needs to join other structures of health, intersectoral, public, community and social networks, incorporating management care tools, including the management of waiting lists (referrals for consultations with specialist, procedures and laboratory tests). In this micro regulatory space, from the horizontal relationship, it ensures access to other points of the network in a timely manner, with fairness ${ }^{(6)}$.

The interest in studying this issue stems from the experience with teaching, research and extension activities in the Family Health Units of a city in the countryside of Rio Grande do Sul. During the moments in practical classes with multidisciplinary undergraduates and residents, one noted that the user's needs are often translated into a referral to another service without his participation.

The assumptions of the research are that with the negotiation and shared decision-making between professionals and users, the referral performed can be a promoter of accountability, both of the professional and of the user; and that, instead, if the referral is a unilateral decision, it can generate a lack of responsibility on the professional's part as well as on the user's part, working as a barrier to equal access to services and compromising the performance of the Unified Health System.

The guiding question of this research was: How can the negotiation and the shared decision-making between professionals and users during practical care in a Family Health Unit make effective the continuity of care in the Health Care Network? Based on the above, the objective was to identify the negotiation and shared decision-making between professionals and users during the care practices in a Family Health Unity and its influence on the continuity of care in the Health Care Network.

\section{Method}

Qualitative research conducted from a case study. The case study is used when one wants to investigate "a contemporary phenomenon in depth and in its real life context, especially when the boundaries between phenomenon and context are not clearly evident" ${ }^{\prime \prime}(39)$.

The five essential components of the case study were considered: study questions; propositions; unit of analysis; coherence that links the data to the propositions; and criteria for interpreting the data.

The unit of analysis, or the "case" was a Family Health Unit from a medium-sized city, located in Rio Grande do Sul, Brazil, in the period from February to July 2012. The spatial limits of the case ${ }^{(9)}$ was a Family Health Unit with two basic teams and one oral health team. The nurses, nurse technicians, community health workers, the dentist and the dentist's assistant joined the Family Health Unit through a civil service examination. The doctor worked on a temporary service contract, as in the civil service examination the vacancy for doctor was not fulfilled. The community health workers had already worked under contract before the civil service examination. There were also on this Family Health Unit the following employees: a receptionist, hired as a cleaning assistant and who, with time, took over the reception; a cleaning person, who also took over the reception in the afternoon; and the unit coordinator, a position of trust from the city government.

The Family Health Unit is not being considered a sample of the other units of the Family Health Strategy of the city, as the case studies "are generalizable to theoretical propositions and not to populations"(9:36).

The three key principles for data collection 
were followed: the use of multiple sources of evidence; the creation of a database; and the maintenance of a connection between this evidence ${ }^{(9)}$. The sources of evidence used were observation, interviews with workers and users and search for documents and records on the information systems.

The observation was participant, unstructured and direct, conducted during the periods in which the Family Health Unit was in operation, especially during care practices. As care practices one considered all the actions involving an encounter between workers and users. Staff meetings, meetings with the community, meetings among team members that occurred informally during work shifts were also observed.

To accomplish the description of the observations one used thorough, detailed and dense work, aiming to capture everything that was happening during the periods studied. With the field diary built, the analysis was facilitated by minimizing conventional thinking ${ }^{(10)}$. Two auxiliary observers with prior training, accompanied the researcher to increase the reliability of the observed data and to avoid bias. To ensure greater reliability of observation, field diaries were elaborated by the researcher and by the assistant, being confronted and discussed later. The time limit for the data collection was from February to July 2012, totaling 76 hours and 25 min.

One conducted 19 interviews and the respondents were: two nurses, two nursing technicians, a doctor, a surgeon dentist, a dentist's assistant, a cleaning person, a coordinator of the family health unit and four community health workers. One also interviewed six users who, during the period of data collection, were guided to another unit of the city's Health Care Network.

The meeting minutes, staff reports, management reports of the City Health Secretariat, diaries of referrals and letters received were the documents analyzed. There should be caution in the use of documents in order to avoid taking them as literal records of what happened, because the document was not drafted for research but for some other specific purpose ${ }^{(9)}$.

To perform the analysis of case study one should pursue the answer to the research question and the established goals, along with the theoretical propositions, which are constantly updated. The data collection should also be mediated by theoretical orientation, with established assumptions that guide the analysis ${ }^{(9)}$. The preparation of the research corpus was the analytic strategy used. Data were revisited several times, allowing the identification of important markers to guide the analysis and avoid an a priori interpretation.

To secure and enhance an ethical conduction during the research process, the guidelines and provisions of Resolution No. 196/96 of the National Health Council were considered. The project was submitted to the Ethics Committee in Research of the Federal University of São Paulo and approved under Protocol number 1939/11. The participation in the survey took place after the subject's acceptance, after participants signed a free informed consent form. Aiming to ensure participants' anonymity, the workers were identified by the profession followed by a number, considering CHA for community health agent; DA for dentist's assistant; COORD. for coordinator; SD for surgeon dentist; NUR. for nurse; D for doctor; RECEP. for receptionist and NT for nursing technician.

\section{Results}

After the analysis of the data it was possible to create two categories: “User's participation in the referral decision: is negotiation possible?" and "Alternative ways to the continuity of care", as shown in the description below. 
User's participation in the referral decision: is negotiation possible?

During the collection period, it was noticed how decisions happened in referrals to other units of the Health Care Network. (Consultation with a doctor) I want a consultation with an ophthalmologist, my glasses are broken. I need to renew my prescription, I can't just have new glasses made. - The doctor makes the referral without speaking, no questions about when the last consultation was, he only provides the form. He also gives no guidance on how to proceed with the referral (Female user) (Field diary, 03/01/12). (Consultation with a doctor) The doctor looks at the chart, opens the examination, it is the result of an ultrasound. She says: It's just a lipoma, just take it out, no need to get nervous. The doctor makes the referral. - User: People say that when you remove one, more may appear. - Doctor interrupts and says: Nothing to do, if more comes it's because it was already coming. - User: When is it going to happen, doctor? I will travel. - Doctor: I don't know, it will be scheduled. - User: Oh, does it have to be scheduled? - Doctor hands in the routing and says: This you can schedule over there and this one (examination) you'll show when they call you. - User leaves without asking any more questions (Field diary, 03/01/12).

In these cases the decisions were unilateral, ie, either the user or the doctor decided what needed to be done. In the interview the doctor explained how this happened: There are patients who come and want, and I try to explain that they do not need it and the patients get offended: How? If it's for everyone, why can't I?. Sometimes I create a subterfuge to explain. The person says: Oh, I need a cardiologist. Why do you want a cardiologist? - Ah, because I've never been to a cardiologist, and I'm 22 years old and occasionally my chest burns before a test, I don't know why ... Then I have to explain. But if the person insists then I already say: If you really want it then go look for other means, because through the reference and counter reference with your complaint I can't get anything to you. We can't send everyone who wants to be referred because it clogs the system and it does not flow. It may not be for who wants, but for who really needs (Interview with a doctor).

However, the technical criterion, highlighted by the doctor, sometimes is not taken into account, as it will be seen as follows. It is worth reflecting on this, because it was observed that the decision of who would be attended first was the receptionist's or the coordinator's and not based on the person's necessity.

The issue of the user's participation in the routing decision discussed during the interview reveals that workers agreed that this can make a difference in the adherence to the therapeutic proposal; the community health agents even gave examples of how this happens: It's already happened to me going to houses and people telling me: Ah, I went there, I complained about one thing to the doctor and she referred me to this, what has it got to do ? [...] That influences them not taking responsibility, not appreciating that consultation (Interview with community health agent 1). We often come in (for the medical consultation), and he does not look at you in the eyes... I'll be telling the story of my (user) there, she comes here and says: Oh, I need a cardiologist, he simply gives the referral. He does not question it: But what is your symptom? (Interview with community health agent 2). It's better for him to face his problem and he should participate because he decided to, because if he has to take such medication, he is aware, he is co-responsible for what he is deciding (Interview with community health agent 3). Because if you give a referral to a person and says: You need to go to this doctor. - And do not say why, what are the consequences of not going? Then you have to get inside the patient's head, explain and make him leave understanding his situation, why he is being referred and what is the consequence if he does not accept it, we must have this synergy with the patient, otherwise, it does not work (Interview with a doctor). It is up to the professional at the interview to discuss, to empower. We will raise awareness: Look, the mammogram showed BI-RADS 4, you have to take an additional exam and that exam is "such", you will have to go to women's health. That is the way we negotiate with her. We make her aware of what is happening, I think that, when we ask for an exam, we have to say why we're asking, otherwise, there is no purpose, when we explain that, we have to wonder if she understood (Interview with Nurse 1).

When considering the testimonies, it may be stated that in some cases, the team had the participation of the user in the decision of the therapeutic proposal. However, in the meetings between worker and user observed, the listening to the user's perspective, the 
initial condition for participation, did not always happen: (Consultation with a doctor) Patient complains of shortness of breath, feeling of choking, and chest pain when walking a bit and says: Can't you refer me? - Doctor interrupts and says: Must be sedentariness (Field diary, 03/01/12). (Consultation with a doctor) A man enters accompanied by his son. - Doctor: Checkup (User's name)? - Man: just checkup. - Doctor looking at the exams: Glucose reaching the limit, high cholesterol, triglycerides horribly high, lipemic serum. - Man: What does that mean? (With scared expression). - Doctor: They separated the white part of your blood from the red part, put the white part in the fridge and it hardened, became fat. Do you use medication? - Man: Only simvastatin. Doctor: Simvastatin does not act on triglycerides, we'll have to fight that too. Do you drink a lot of milk? Milk in the morning and during the day? - Man: No - Doctor: How is your breakfast? - Man: Coffee, black and I like tea. - Doctor: What's your weight now? - Man: I don't know. (Visibly overweight). - Doctor: I'll send you to a nutritionist! So that you don't have a heart attack (Name)! - Man: What kind of food increases triglycerides? - Doctor: Fat. - Man: Only fat? - Doctor: Fat and sweets! Decrease fat and exercise. What do you do? - Man: I am bricklayer, but I go to work and come back home by bike, an hour or half an hour of biking everyday. Will you change simvastatin? - Doctor guides the patient about the referral. - Man: Do I have to set an appointment for the nutritionist? - Doctor: Yeah! (He talks and writes down ICD 10) Done, now yes. - Man: What is the name of the place I'll have to go? Write it here in the back to me. - He explains the location. Man leaves (Field diary, 03/15/12).

The user demonstrated interest to know more about his condition, but received little information. The referral to the nutritionist was not guided or negotiated and the conversation in the consultation was headed towards medication.

It was observed that during dental treatment users were informed about the possibilities, enabling their participation in the conduction of decisions, as follows: (Consultation with the dentist): You are still able to keep your teeth, we can stop this disease, but you still have to come several times. I'm removing tartar, from this tooth here I will not be able to remove (tartar) because if I remove, it will fall. My advice is that you have it taken out, but you are the one who decides, but it is not good to leave it, there are bacteria, sooner or later it will fall, but it is up to you. - After the examination, the dentist asks: Do you have any questions? - Man: No, it's because I'm old now, isn't it? Just keep like this, I can get by, can't I doctor? - Dentist: Bring your toothbrush next consultation inside a bag. - Man: We know we have to brush our teeth more, but you know how things are. - Dentist: Sometimes it's the only way. - Man leaves (Field diary, 03/12/12).

The surgeon dentist encouraged the user to participate in the decision about his oral health, but the acceptance of the proposal to retain the teeth was related to the vision that he had about the future of his teeth, which was different from the surgeon dentist, and it was possible to establish the continuity of care. (Consultation with the dentist): I wrote here that it is a dental extraction on this side and we will continue cleaning. What do you think? - Man: Mm hmm. - Dentist: If you can stay at home, waste end up staying on the teeth, so it is important a periodic cleaning. Let's see your BP (Blood Pressure) (Field diary, 04/17/12).

Moments like these, in which the user was invited to participate in the decision of his care, were rare. One of the characteristics of the work organization of the team was the fact that the privacy of the meeting was not prioritized, except for Pap collection, in which the room was looked. In the dental office the concern of the dental health team to ensure that space was seen: The dentist was already attending and on the door there were two notes that said: Do not knock on the door, we are in consultation. To speak with a dentist or auxiliary wait for the end of the patient's consultation. Dear User: we only schedule one moment per person. No exceptions. Thank you for understanding (Field diary, 04/17/12).

Therefore, triangulating the information of little privacy, lack of listening and widespread conception that the team had about users, even with the idea that the user's participation is necessary, the negotiation and shared decision-making were harmed. 


\section{Alternative ways for the continuity of care}

In contrast, one highlights the ways that users can use to access the health care network. It was identified that the relational component was implied and one of them was called 'via coordinator'.

In a home visit it was observed that this way is an alternative that alleviates suffering, when it meets the users' needs: A user said that she felt a sharp pain in her chest, went to the family health unit and was referred to a cardiologist. He added a medication (Isocordil). Researcher: How did you manage a consultation with a cardiologist so fast? - Female user: The coordinator got it for me, he managed an extra consultation, because the doctor said it was urgent (Field diary, 04/03/2012).

However, emergencies are not always prioritized by the coordinator; if the user knows this possibility, he looks for it, regardless of technical criteria: The coordinator is talking to a lady. She wants to know about a referral to a neurologist. Coordinator: Do you have the doctor's referral - Lady: It's in my daughter's house. - Coordinator: So bring it to me. - Lady: Today? This morning? - Coordinator: It could be. The interest is yours (Field diary, 03/30/12).

The cleaning person that worked in the reception in the afternoon confirmed in the interview that the user defined the urgency of the request, not the technical evaluation of the case: Researcher: In the request it is written why it is being forwarded, do you look at it or is it just what the user says? - Server: No, it's just what the user says, (Silence) he asks to schedule, to set an appointment. - Researcher: So the urgency is given when the user says 'I need it fast'? - Server: Yes, it is. (Interview with the cleaning person).

Therefore, when this cleaning person was in the reception any user who verbalized that he needed an appointment urgently had his request forwarded to the coordinator, who sped it up. The technical criteria, in these moments, were ignored. However, the team also set appointments 'via coordinator' when they identified an urgent case: Nurse 2 after assessing an injury: He has a very characteristic arterial ulcer, I referred him to an angiologist. She guides the user's companion to take the request to the reception. - When she gets to the reception the coordinator receives the request. Nurse 2 also arrives at the reception. The coordinator asks the data to the lady and says: If I leave it here it will take too long, but as today in the afternoon I'm going to the Secretariat I can set the appointment there, directly with (Name of the City Health Secretary). - Nurse 2 agrees (Field diary, 03/12/12).

During an interview with the coordinator this subject was taken up and he explained that he used spare vacancies from other units and that he was willing to make the relocation of those vacancies, which was confirmed with the regulation sector from the City Health Department. The information was that when the patient was not found, or when the units failed to contact patients, or when the patient gave up, they resorted to the units, which "chased" other users to fit in the spare vacancies. One of them was the Family Health Unit studied, represented by its coordinator. That is, the City Health Secretariat did not have a priority list, or did not identify who were the users that needed to be attended first, so called the ones who could be contacted.

\section{Discussion}

Decisions about referrals to other points of the Health Care Network were unilateral, either the user or the health care professional decided what needed to be done. When a decision is unilateral in a negotiation, it means that the interests of one of the people involved are valued over another, ie, that without the participation of the other person, one side makes the decision that seems the most convenient for himself.

A study about humanization practices in health care reflects the need of professionals to resignify their practice, humanizing it, understanding that there is always a lot to learn and to share with others. It was also felt that due to the attention model that prevails in the health system, the unilaterality in the guidelines and decision-making values the scientific knowledge 
instead of the popular knowledge. However, what is sought is a closer relationship between these two kinds of knowledge $\mathrm{e}^{(11)}$.

Still, the decisions made by health professionals, when they are unilateral, without the participation of the users and their families, are in agreement with another study that reveals that families appreciate a health team that demonstrates respect, listening and commitment $^{(12)}$. For users and professionals to define together the behaviors and referrals it is necessary to implement qualified hearing systems to ensure an analysis based on the problems presented ${ }^{(13)}$. Even when there is a work based on speaking and listening, in which one seeks care where there is space to learn from each other, sometimes the practice remains focused on the drug protocol, leaving aside other strategies to implement attention practices ${ }^{(14)}$.

Furthermore, assessments of risk and vulnerability should comprehend a dialogical process between professionals and users and should not be unilateral, as identified during the research. Listening the evaluation that users make of the situation is an attitude of respect and support for the construction of autonomy, contributing to self-care ${ }^{(15)}$.

So when the user demonstrates wanting to know more about his health problems, his right to information should be guaranteed, and that this action is extended to his family and companions. This piece of information should be provided in a clear, objective, respectful, understandable way and adapted to the cultural conditions and respecting the ethical limits on the part of health professionals, always aiming to clarify the risks and benefits that involve the user ${ }^{(16)}$.

Confirming this, a study on the importance of communication noted that the provision of clear and understandable explanations, according to the needs of the user that allows one to reach a consensus on the treatment plan, and establishing a mutually acceptable plan can facilitate decision-making ${ }^{(3)}$.
In terms of adherence to the medication treatment, a study shows that the perception and knowledge of the patient about the expected treatment benefits lead to a larger adherence. On the other hand, it is seen that the level of knowledge of the patient is rarely investigated by health professionals in clinical practice $^{(17)}$. Therefore, it is very important that there is dialogue between the healthcare team and users, highlighting the need for an expanded listening and establishing a bond of mutual respect ${ }^{(18)}$.

In the absence of dialogues, agreements and trust for one another, alternative ways are created to provide the continuity of care, such as doing things 'via coordinator' to access the Health Care Network of the city studied. One can interpret this as the "Brazilian way"(19), which is the way that is used to navigate socially in Brazil, even having a rule or law that says 'you can't'. Here it is noted that it is used when the public sector fails, in this case the regulation, making impractical the queue and the wait.

Interestingly, the health team also makes use of this way when they assess the situation as urgent, or it may be suggested, when they are sensitized with the case, indicating the need for different strategies from the ones available. The challenge in this situation is to put the principle of fairness in action, establishing transparent criteria for deciding the priorities that ensure access to the Health Care Network, as it already happens in some Brazilian cities.

As it is stated by the health users' letter of rights: that the referrals should take into account the seriousness of the problem according to the need and also the clinical indication ${ }^{(16)}$. The availability of information and transparency with them allow the regulation and continuity of care to happen ${ }^{(20)}$.

Dealing with transparency, the "Brazilian way" could be used by health workers, in an implied manner, to defend the comprehensiveness of care. Allowing everyone to know the criteria leads us to the 
public sphere in the sense that "the presence of others who see what we see and hear what we hear assures us the reality of the world and of ourselves"(22:60). With the security given by advertising and implication, one could define the cases that arrived first, considering technical issues, but also the subjectivity and uniqueness of each individual, because "the uniqueness of each person transcends the sum of his qualities"(21:222).

The transparency of the "Brazilian way" to the conduction of equity can be interpreted as the exit of obscurity and entrance into the public sphere, and it needs to be exposed so that one can "get some form of existence." However, it cannot to be confused with kindness, because this quality is unique to the private sphere ${ }^{(21: 85)}$. "In the moment that a good job becomes known and public, it loses its specific character of kindness, of not being done for any other reason beyond the love of goodness"(21:86).

Translating to the reality studied, it is possible to say that taking responsibility for the needs of each case waives the establishment of criteria defined and constructed with the participation of the population, publicly. Otherwise, it would become favoring of some over others, contradicting the very meaning of kindness. Therefore, one is not speaking about kindness, but about a public commitment to the production of health and the construction of citizenship because "The distribution of benefits for some and difficulties for others, are ways of dividing things to maintain an order that interests someone"(22:81).

\section{Final Considerations}

It was possible in this article to compare the available discourses, hegemonic and counterhegemonic, analyzing the gaps that they produce. It allowed one to capture moments of silence, needs and desires of users and workers of a Family Health Unit, identifying some enemies of the user's participation in the decision for the continuity of care. Returning to the assumptions, it is recognized that the negotiation and shared decision-making between workers and users to perform the doctor's referral was not identified, lacking evidence for its substantiation. The referral, most of the times was a unilateral decision, either the user's or the worker's, but in both cases the user was alone in the quest for access.

The respect for the user's participation in the decision about his health/disease process in a Family Health Unit was verbalized by the team, but hardly ever found in healthcare practices. It is argued that the health care worker cannot speak and decide by the user. Listening becomes essential, with the user's participation being deliberately encouraged to promote dialogue, which may be decisive in the continuity of care.

It is necessary to admit that the subject of negotiation and shared decision-making is very little addressed in health education, and it lacks a previous discussion that is the backdrop for this to happen, which is the recognition of the uniqueness of each individual. Anyway, it is worth remembering the roles of the university: the accountability for making this agenda a constant topic in undergraduate and postgraduate health courses, as well as in continuing education; do research and produce knowledge that is inserted into a critical theory, committed with the objects of study, not only to detect problems, but also to contribute to the construction of possible ways.

In the city studied, the management of Primary Care needs to be studied, worked and built to advance in the consolidation of this environment, as a space that welcomes, links, solves the health problems and takes responsibility for the user's access to other points of the Health Care Network. A Primary Care management that enables it to take the ordination of the Health Care Network, as it is mainly in the Primary Care that this link is possible, from the perspective that one can know what the users need, making pacts with the city administration in the struggle for ensuring the continuity of care. 


\section{Collaborations}

Schimith MD contributed with the field research and participated in all stages of production of the article. Brêtas ACP and Budó MLD contributed with the research orientation. Simon BS contributed with data collection, writing and critical analysis of the article. Leal TC and Backes DM contributed with the elaboration and critical revision of the article.

\section{References}

1. Ministério da Saúde (BR). Secretaria de Atenção à Saúde, Departamento de Atenção Básica. Acolhimento à demanda espontânea. Brasília: Ministério da Saúde; 2011.

2. Buss PM. Uma introdução ao conceito de promoção da saúde. In: Czeresnia D, Freitas CM. Promoção da Saúde: conceitos, reflexões, tendências. Rio de Janeiro: Fiocruz; 2009. p.15-38.

3. Politi MC, Street Jr RL. The importance of communication in collaborative decision making: facilitating shared mind and the management of uncertainty. J Eval Clin Pract. 2011; 17(4):579-84.

4. Mendes EV. As redes de atenção à saúde. Brasília: Organização Pan-Americana da Saúde; 2011.

5. Organización Panamericana de la Salud/ Organización MundialdelaSalud. Redes integradas de servicios de salud: conceptos, opciones de política y hoja de ruta para su implementación en las Américas. Washington, D.C.: OPS/OMS; 2010 (Serie La Renovación de la Atención Primaria de Salud en las Américas no 4). Disponible en: http://new.paho.org/hq/index.php?option=com content\&task=view\&id=5520\&Itemid=25\&lang

6. Ministério da Saúde (BR). Portaria no 4.279/2010. Estabelece diretrizes para a organização da Rede de Atenção à Saúde no âmbito do Sistema Único de Saúde (SUS). Brasília: Ministério da Saúde; 2010.

7. Conill EM, Fausto MCR, Giovanella L. Contribuições da análise comparada para um marco abrangente na avaliação de sistemas orientados pela atenção primária na América Latina. Rev Bras Saúde Matern Infant. 2010; 10(Supl.1):15-27.
8. Ministério da Saúde (BR). Secretaria de Atenção à Saúde, Departamento de Atenção Básica. Política Nacional de Atenção Básica. Brasília: Ministério da Saúde; 2011.

9. Yin RK. Estudo de caso: planejamento e métodos. $4^{a}$ ed. Porto Alegre: Bookman; 2010.

10. Becker HS. Segredos e truques da pesquisa. Rio de Janeiro: Zahar; 2007.

11. Badke MR, Budó MLD, Alvim NAT, Zanetti GD, Heisler EV. Popular knowledge and practices regarding healthcare using medicinal plants. Texto Contexto Enferm. 2012; 21(2):363-70.

12. Camatta MW, Nasi C, Adamoli NA, Kantorski LP, Schneider JF. Evaluation of a psychosocial care center: the view of the family. Ciênc Saúde Coletiva. 2011; 16(11):4405-14.

13. Ministério da Saúde (BR). Secretaria-Executiva, Núcleo Técnico da Política Nacional de Humanização. HumanizaSUS: Política Nacional de Humanização: a humanização como eixo norteador das instâncias do SUS. Brasília: Ministério da Saúde; 2004.

14. Abrahão AL, Souza RF. The work of nurses in the family health strategy -aspects of promoting health practice. Rev Rene. [periódico na Internet]. 2013 [citado 2014 jan. 13]; 14(4):740-7. Disponível em: http://www.revistarene.ufc.br/revista/index. php/revista/article/viewFile/1000/pdf

15. Ferreira JBB, Mishima SM, Santos JS, Forster AC, Ferraz CA. O complexo regulador da assistência à saúde na perspectiva de seus sujeitos operadores. Interface Comum Saúde Educ. 2010; 14(33):1-14.

16. Ministério da Saúde (BR). Carta dos direitos dos usuários da saúde. $3^{\underline{a}}$ ed. Brasília: Ministério da Saúde; 2011.

17. Rubin RR. Adherence to pharmacologic therapy in patients with type 2 diabetes mellitus. Am J Med. 2005; 118(Suppl 5A):27-34.

18. Marin MJS, Martins APMF, Feres BOM, Saraiva AKH, Druzian S. A atenção à saúde do idoso: ações e perspectivas dos profissionais. Rev Bras Geriatr Gerontol. 2008; 11(2):245-58.

19. DaMatta R. 0 que faz o brasil Brasil? Rio de Janeiro: Rocco; 2001. 
20. Giovanella L, Mendonça MHM, Almeida PF, Escorel S, Senna MCM, Fausto MCR et al. Saúde da família: limites e possibilidades para uma abordagem integral à saúde no Brasil. Ciênc Saúde Coletiva. 2009; 14(3):783-94.
21. Arendt H. A condição humana. 10 a ed. Rio de Janeiro: Forense universitária; 2001.

22. Freire P. Pedagogia do oprimido. 17a ed. Rio de Janeiro: Paz e Terra; 1987. 